\title{
Adequacy of high-risk prenatal care at a referral hospital
}

\author{
Adequação do pré-natal de alto risco em um hospital de referência
}

Lediana Dalla Costa ${ }^{1}$, Alessandro Rodrigues Perondi ${ }^{1}$, Jolana Cristina Cavalheiri ${ }^{1}$, Andressa de Souza Ferreira ${ }^{1}$, Géssica Tuani Teixeira ${ }^{1}$, Durcelina Schiavoni Bortoloti ${ }^{1}$

Objective: to describe the adequacy of prenatal care for high-risk pregnancy in a referral hospital. Methods: descriptive, retrospective and documentary study. The sample was 73 pregnant women who had a childbirth, during the collection period. The Kessner index was used to assess the quality of care, validated instrument in Brazil. For analysis of the information, descriptive statistics and distribution of relative frequencies were used. Results: among the 73 pregnant women, $47.9 \%$ were young adults, $50.7 \%$ were married, and $52.0 \%$ had only primary level. According to the Kessner Index, the intermediate adjustment prevailed. Conclusion: the main finding of this study was the intermediate adequacy of prenatal high risk. It was also found that pregnant women initiated prenatal care late in high risk, leading to reduced number of consultations, clinical procedures, obstetric and laboratory tests.

Descriptors: Prenatal Care; Pregnancy, High-Risk; Quality of Health Care; Health Evaluation.

Objetivo: descrever a adequação da assistência pré-natal de gestação de alto risco em um hospital de referência. Métodos: pesquisa descritiva, retrospectiva e documental. Amostra constituída por 73 gestantes que tiveram como desfecho o parto, no período da coleta. Foi utilizado para avaliação da qualidade da assistência o índice de Kessner, instrumento validado no Brasil. Para análise das informações, foi utilizada estatística descritiva e distribuição das frequências relativas. Resultados: dentre as 73 gestantes, 47,9\% eram adultas jovens, 50,7\% eram casadas e 52,0\% tinham apenas o nível fundamental. De acordo com o Índice de Kessner prevaleceu à adequação intermediária. Conclusão: o principal achado deste estudo foi à adequação intermediária do prénatal de alto risco. Verificou-se ainda que as gestantes iniciaram o pré-natal tardiamente no alto risco, o que ocasionou número reduzido de consultas, procedimentos clínicos obstétricos e exames laboratoriais.

Descritores: Cuidado Pré-natal; Gravidez de Alto Risco; Qualidade da Assistência à Saúde; Avaliação em Saúde.

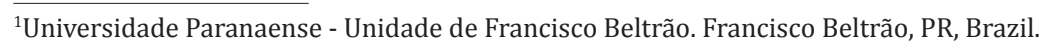

Corresponding author: Lediana Dalla Costa

Rua São Francisco de Assis, 230 - CEP: 85604-180 - Cango. Francisco Beltrão, PR, Brazil. E-mail: lediana@unipar.br 


\section{Introduction}

A quality prenatal care is essential, aiming to accommodate pregnant women from early pregnancy to monitor gestational risk factors, obstetrical therapeutic interventions, immunization and prophylaxis, counseling and health education ${ }^{(1)}$. Maternal mortality is a major public health problem in Brazil, with varied causes according to the level of development of each region of the country ${ }^{(2)}$.

In all pregnancies, prenatal monitoring starts in the reference basic health unit of each neighborhood and the city of residence of the pregnant woman. In the first medical consultation or nursing, the mother is classified as normal risk, then the doctor or nurse is responsible for checking the obstetric history, diseases or injuries, individual and sociodemographic conditions, pre-existing medical conditions or having medical complications to continue to follow the usual risk or possible follow-up to the intermediate-risk or high-risk ${ }^{(3)}$.

Thus, the assessment of prenatal care is essential in care planning, aiming to prevent, diagnose and treat adverse events during pregnancy, childbirth and care of the newborn ${ }^{(4)}$, and allow the reorganization of services and actions as the real customer needs.

Currently, the literature has several indexes that assess the quality of prenatal care, such as the Kessner Index created in 1973, adapted and validated by Takeda in Brazil in $1993^{(5)}$ to assess the quality of prenatal care, according to the number of visits, gestational age, number of clinical and obstetric procedures performed and the record of laboratory tests in the medical charts ${ }^{(5-6)}$.

From this premise, the aim of this study was to describe the adequacy of prenatal care for high-risk pregnancy in a referral hospital.

\section{Methods}

This study is characterized as a descriptive, retrospective, and documentary type, developed in a high-risk pregnancy clinic of a Regional Hospital, to check the appropriate care to prenatal care, according to a quality instrument, validated ${ }^{(5)}$ in Brazil.

The participants of this study consisted of medical records of women who met the inclusion criteria: being sent to the prenatal service of high risk in the studied hospital, located in the municipality of Francisco Beltrão, PR, Brazil and had a childbirth in the period from March to August 2015.

Every medical record had random numbers to preserve the confidentiality of identifying pregnant women. The following data were collected: current age, marital status, educational level, gestational age who initiated prenatal care in primary health care. Based on the records of the patient, the four quality levels were also analyzed, according to Kessner index, modified by Takeda in 1993.

Level 1 - the quality of prenatal evaluated by the number of consultations and early prenatal care. At this level, prenatal service is classified into three categories: appropriate (having a record of six or more consultations and early prenatal care before 20 weeks), inadequate (early prenatal after 28 weeks or less than three visits) and intermediate (in other cases).

Level 2 - prenatal quality measured by the number of consultations, early prenatal care and clinical/obstetrical procedures as technical manual ${ }^{(1)}$ : adequate (having record of six or more visits, prenatal onset before 20 weeks, five or more records each of the following procedures: blood pressure, weight, gestational age, records of uterine height and four or more records of the fetal heart rate and fetal movements), inadequate (early prenatal care after 28 
weeks, or less than three consultations, two or fewer records of blood pressure, weight, gestational age, records of uterine height and four or more records of the fetal heart rate and fetal movements) and intermediate (in other cases).

Level 3 - quality of prenatal evaluated by the number of consultations, early prenatal care and laboratory tests recommended by the Program for Humanization of Prenatal and Birth: adequate (six or more visits, prenatal early registration before 20 weeks and a record of tests: blood typing and the presence of the $\mathrm{Rh}$ factor $(\mathrm{ABO} / \mathrm{RH})$, hemoglobin and hematocrit, examination of syphilis, qualitative urinalysis, fasting glucose test to detect antibodies to the virus of human immunodeficiency (HIV) and toxoplasmosis in the first consultation, and new clinical exams next to the $30^{\text {th }}$ week of pregnancy: syphilis, qualitative urinalysis, fasting glucose, HIV testing, audit for the virus surface antigen hepatitis B (HBsAg)), inadequate (early prenatal care after 28 weeks, less than three consultations and no record of exams) and intermediate (all other situations).

Level 4 - quality of prenatal evaluated by the number of consultations, early prenatal care, clinical/obstetrical procedures and laboratory tests: adequate (having record of six or more visits, prenatal onset before 20 weeks, five or more records of blood pressure, weight, gestational age, records of uterine height and four or more records of the fetal heart rate and fetal movements and at least one of the tests: $\mathrm{ABO} / \mathrm{Rh}$, Hematocrit/Hemoglobin, syphilis, qualitative urinalysis, fasting glucose, HIV testing and toxoplasmosis in the first consultation, and new clinical exams next to the $30^{\text {th }}$ week of pregnancy: syphilis, qualitative urinalysis, fasting glucose, HIV testing and HBsAg test), inadequate (early prenatal care after 28 weeks, or less than three consultations, two or fewer records blood pressure, weight, gestational age, records of uterine height and four or more records of the fetal heart rate, fetal movements and no record of exams) and intermediate (in other cases).

For the information analysis, descriptive statistics were used to characterize the sample and distribution of relative frequencies with a confidence interval (CI) of $95.0 \%$ when the event number was greater than five. The for specific software Statistical Package for the Social Sciences version 20.0 and BioEstat program version 5.4 were used.

The study complied with the formal requirements contained in the national and international regulatory standards of research involving human beings.

\section{Results}

There were 73 births to women who underwent high-risk prenatal care in the clinic of the hospital during the period of data collection. The average age of patients was $27.6 \pm 7.1$ years old.

As the epidemiological profile of pregnant women, there was a predominance of pregnant women aged between 26 and 35 years old (47.9\%), followed by pregnant women aged between 16 and 25 years old (41.0\%) and 36 and 43 years old (11.0\%). Regarding marital status, there was a predominance of married women (50.7\%), followed by women with stable and single Union, respectively $28.8 \%$ and $20.5 \%$. Regarding education, there was a complete primary level (52.0\%), followed by medium level (37.0\%) and higher education (11.0\%).

In Table 1, there is the beginning of prenatal care in primary health care and early prenatal care in the high risk. It was noted that most of the women began prenatal care in primary health care before 20 weeks (87.7\%). However, prenatal care in the high risk was started after 28 weeks of gestation (58.9\%). Regarding the number of consultations in the high-risk clinic, $50.7 \%$ of pregnant women conducted between five and three visits during the prenatal period. 
Table 1 - Prenatal characterization in the primary health care and high risk, and number of visits to the referral hospital

\begin{tabular}{lcc}
\hline Variable & $\mathbf{\%}$ & IC $\mathbf{( 9 5 \% )}$ \\
\hline Early prenatal care in primary health care (in weeks) & \\
$\quad<20$ & 87.7 & $80.1-95.2$ \\
$21-27$ & 8.2 & $1.9-14.5$ \\
$>28$ & 4.1 & - \\
Early high risk prenatal (in weeks) & & \\
$\quad<20$ & 11.0 & $3.8-18.1$ \\
$21-27$ & 30.1 & $19.6-40.7$ \\
$>28$ & 58.9 & $47.6-70.2$ \\
Consultations at high risk & & \\
$\quad$ Adequate $(\geq 6)$ & 19.2 & $10.1-28.2$ \\
Intermediate $(5-3)$ & 50.7 & $39.2-62.2$ \\
Inadequate $(\leq 2)$ & 30.1 & $19.6-40.7$ \\
Total & 100.0 & - \\
\hline
\end{tabular}

According to the records of clinical/obstetrical procedures, the evaluation of the prenatal care service was considered as intermediate (39.7\%), from the measurement of blood pressure, weight, gestational age, uterine height and fetal heartbeats or fetal movements (Table 2).

Table 2 - Adequacy prenatal characterization, according to clinical/obstetrical procedures, performed in a reference hospital

\begin{tabular}{|c|c|c|}
\hline Variables & $\%$ & IC $(95 \%)$ \\
\hline \multicolumn{3}{|c|}{ Blood pressure (records) } \\
\hline$\geq 5$ & 32.9 & $22.1-43.7$ \\
\hline $3-4$ & 37.0 & $25.9-48.1$ \\
\hline$\leq 2$ & 30.1 & $19.6-40.7$ \\
\hline \multicolumn{3}{|c|}{ Weight (records) } \\
\hline$\geq 5$ & 34.3 & $23.4-45.1$ \\
\hline $3-4$ & 35.6 & $24.6-46.6$ \\
\hline$\leq 2$ & 30.1 & $19.6-40.7$ \\
\hline \multicolumn{3}{|c|}{ Gestational age (records) } \\
\hline$\geq 5$ & 31.5 & $20.9-42.2$ \\
\hline $3-4$ & 35.6 & $24.6-46.6$ \\
\hline$\leq 2$ & 32.9 & $22.1-43.7$ \\
\hline \multicolumn{3}{|c|}{ Uterine height (records) } \\
\hline$\geq 5$ & 23.3 & $13.6-33.0$ \\
\hline $3-4$ & 34.2 & $23.4-45.1$ \\
\hline$\leq 2$ & 42.5 & $31.1-53.8$ \\
\hline \multicolumn{3}{|c|}{ Fetal heartbeats or fetal movements (records) } \\
\hline$\geq 5$ & 24.6 & $14.8-34.5$ \\
\hline $3-4$ & 32.9 & $22.1-43.7$ \\
\hline$\leq 2$ & 42.5 & $31.1-53.8$ \\
\hline Adequate & 31.5 & $20.9-42.2$ \\
\hline Intermediate & 39.7 & $28.5-51.0$ \\
\hline Inadequate & 28.8 & $18.4-39.2$ \\
\hline Total & 100.0 & - \\
\hline
\end{tabular}

The adequacy of prenatal care according to laboratory tests showed a predominance of intermediate category (91.8\%). Probably, these results are due to the low records of the tests of blood type, Rh, glucose and toxoplasmosis factor (Table 4).

Table 3 - Adequacy prenatal characterization, according to laboratory tests conducted in a referral hospital

\begin{tabular}{|c|c|c|}
\hline Variable & $\%$ & IC $(95 \%)$ \\
\hline \multicolumn{3}{|c|}{ ABO-Rh (records) } \\
\hline 0 & 71.2 & $60.8-81.6$ \\
\hline 1 & 28.8 & $18.4-39.2$ \\
\hline$\geq 2$ & - & - \\
\hline \multicolumn{3}{|c|}{ Hemoglobin/Hematocrit (records) } \\
\hline 0 & 31.5 & $20.9-42.2$ \\
\hline 1 & 28.8 & $18.4-39.2$ \\
\hline$\geq 2$ & 39.7 & $28.5-51.0$ \\
\hline \multicolumn{3}{|l|}{ VDRL (records) } \\
\hline 0 & 6.8 & - \\
\hline 1 & 61.7 & $50.5-72.8$ \\
\hline$\geq 2$ & 31.5 & $20.9-42.2$ \\
\hline \multicolumn{3}{|l|}{ Urine (records) } \\
\hline 0 & 37.0 & $25.9-48.1$ \\
\hline 1 & 30.1 & $19.6-40.7$ \\
\hline$\geq 2$ & 32.9 & $22.1-43.7$ \\
\hline \multicolumn{3}{|c|}{ Glycemia (records) } \\
\hline 0 & 58.9 & $47.6-70.2$ \\
\hline 1 & 26.0 & $16.0-36.1$ \\
\hline$\geq 2$ & 15.1 & $6.9-23.3$ \\
\hline \multicolumn{3}{|l|}{ HIV (records) } \\
\hline 0 & 6.8 & \\
\hline 1 & 67.2 & $56.3-77.9$ \\
\hline$\geq 2$ & 26.0 & $16.0-36.1$ \\
\hline \multicolumn{3}{|c|}{ Toxoplasmosis (records) } \\
\hline 0 & 67.2 & $56.3-77.9$ \\
\hline 1 & 16.4 & $7.9-24.9$ \\
\hline$\geq 2$ & 16.4 & $7.9-24.9$ \\
\hline \multicolumn{3}{|l|}{ HBsAg (records) } \\
\hline 0 & 5.5 & - \\
\hline 1 & 65.7 & $54.9-76.6$ \\
\hline$\geq 2$ & 28.8 & $18.4-39.2$ \\
\hline Adequate & 5.5 & - \\
\hline Intermediate & 91.8 & $85.5-98.1$ \\
\hline Inadequate & 2.7 & - \\
\hline Total & 100.0 & \\
\hline
\end{tabular}

Based on quality levels (Table 4) it was observed that prenatal care was predominantly classified as intermediate in the four levels of the instrument.

Table 4 - Adequacy high risk prenatal performed in a reference hospital

\begin{tabular}{cccc} 
Level (n=73) & Adequate(\%) & Intermediate(\%) & Inadequate(\%) \\
\hline 1 & 4.1 & 68.5 & 27.4 \\
2 & 4.1 & 68.5 & 27.4 \\
3 & - & 95.9 & 4.1 \\
4 & - & 98.6 & 1.4
\end{tabular}




\section{Discussion}

This study used rigorous documental analysis, quantitative in records, which allowed analyzing the adequacy of high risk prenatal, according to the Kessner index. As the main finding, there is the adequate level classified as category "intermediate" for prenatal of a medium-sized municipality of Paraná, Brazil.

However, this study has limitations that should not be overlooked, such as the use of secondary data; the quality of records associated with the lack of registration of all professionals involved in prenatal care (primary care to high-risk care); the time of data collection; the sample size since the sample consisted of only 73 records of pregnant women who had a delivery; and the uniqueness of the reference service as difficulties in risk classification in primary care and late referral to the reference service.

However, it should be noted that the late referral may be due to the decreased number of vacancies offered in the specialized service of the hospital, assisting 27 municipalities of the $8^{\text {th }}$ Regional Health.

On the different factors that can interfere with prenatal care, it is known that age, insecure marital status and low education are pregnancy risk factors that directly interfere in this process ${ }^{(1)}$. Data from this study showed a predominance of young adult pregnant women with low education, married or in stable relationships. These data were below the previous study, in which $64.0 \%$ of the women were young adults, $57.0 \%$ had up to eight years of study, and $86.0 \%$ lived with a partner ${ }^{(6)}$.

Concerning age, it is seen that those with lower age have greater difficulty in adherence to care measures in the prenatal and understanding of their health status, together with a low education that can contribute to the lack of risk and no proper monitoring of prenatal care. Unstable marital status can directly affect the psychological factor because mothers may feel alone and insecure ${ }^{(1)}$.
Early initiation of prenatal care and constant evaluation of its quality are essential for the prevention of complications during pregnancy ${ }^{(7)}$. It was found a satisfactory percentage (87.7\%) from the beginning of previous prenatal to 20 weeks of gestation in basic health care, yet the starting over 28 weeks in the high prenatal risk presented worrying data (58.9\%).

On the other hand, a study conducted in a large urban center in Brazil showed that pregnant women entered in the monitoring of prenatal on average 11.7 weeks of gestation and were referred to the specialized service at low risk on average 24.2 weeks of pregnancy ${ }^{(8)}$. It was not possible to compare data from the beginning of prenatal care in the high-risk clinic, considering that this is a new process and still lacking in scientific studies. Thus, the result of this study suggests that there is a delay in the referral of these pregnant women to specialized service reference, which may cause a delay in starting the correct treatment and, thereby, major complications.

In reference guide to high-risk prenatal, there was the distant date forwarding request the first appointment at the clinic of the hospital. So apparently the fact that pregnant women be classified as high risk, not ensuring their easy and quick access to tertiary service. On the other hand, late referrals may occur due to the emergence of a risk factor for pregnant women during the second or third trimester of pregnancy.

Another factor that can affect the quality of prenatal care is the number of consultations during pregnancy. This study showed that $50.7 \%$ of pregnant women conducted between five and three visits in the high-risk clinic and only $19.2 \%$ had six or more visits. This data contrasts the results of a previous study ${ }^{(9)}$, in which $52.7 \%$ of pregnant women attended six or more visits. It is believed that this difference may be due to the late start in the high risk prenatal, the distance traveled by the pregnant women who come from other cities to Francisco Beltrão, the low maternal education and the lack of primary care records in the ID card of 
pregnant women during monitoring.

The number of consultations can also influence the quality of clinical and obstetrical procedures. In this study, these procedures were carried out properly only in $31.5 \%$ of services. On the other hand, there was intermediate suitability classification in $39.7 \%$ of procedures. Lower data reported in a recent study ${ }^{(10)}$ found that at least a quarter of pregnant women had inadequate prenatal care, the inadequate prenatal index for the municipality in 2010 was $28.0 \%$. However, this study points out that the simple measure of the number of prenatal consultations and the gestational age at which this consultation is carried out may, in fact, mean that care Minimum to adequate prenatal care are ensured ${ }^{(10)}$.

Laboratory tests are essential for the diagnosis of diseases that can be harmful and even lethal during pregnancy. The study shows an intermediate adjustment in $91.8 \%$ of prenatal and only $5.5 \%$ of care was classified as adequate. However, the literature shows that $60.9 \%$ of prenatal may have registered laboratory tests ${ }^{(9)}$. On the other hand, there can still be a scarce repetition of examinations, particularly blood glucose, syphilis and urine ${ }^{(11)}$.

It is important to note that the health unit access is the key point for the host in primary care, where the pregnant woman should have a humanized care $^{(12)}$. In this sense, the nurse is the professional who is in charge of coordination and is responsible for managing each and every service. However, previous research shows that nurses perform any and clinical care in nursing consultations ${ }^{(13)}$. Moreover, the record by professionals in the medical records of patients must be carefully managed, since it indicates the actions taken and allows a sequence of continuity offered assistance, proving the service provided ${ }^{(14)}$, and the lack of information on the requested examinations and recording the results can be evaluated as recklessness, negligence or incompetence ${ }^{(15)}$.

It is noteworthy that despite the public health discussions to create a horizontal line of service, each service has its specific role, its characteristics, and its well-defined function. There is no hierarchy of the services to promote the integrity of the Unified Health System ${ }^{(16)}$. There are apparently still weaknesses in the service offered to pregnant women, as well as continuous training of the professionals involved in this process. Thus, this study may help future research to assess and identify the difficulties encountered in service and to propose improvements in quality of care.

\section{Conclusion}

The results of this study indicated intermediate adequacy of high risk prenatal, according to the Kessner index adapted by Takeda. It was also found that pregnant women initiated late their high-risk prenatal care, which led to reduced number of consultations, clinical and obstetrical procedures and laboratory tests. Also, they identified inconsistencies in completing the records associated with failure to register for assistance to pregnant women.

Thus, despite the new public health efforts to create lines to stratify pregnant women and accept it, it is recommended the development of research to monitor and verify the quality of care in public health services. It is suggested that health professionals are routinely trained in the care of pregnant women.

\section{Collaborations}

Costa LD and Ferreira AS contributed to the project design, analysis and interpretation of data, article writing and critical review of relevant intellectual content and final approval of the version to be published. Perondi AR, Cavalheiri JC Teixeira GT and Bortoloti DS contributed to writing the article and relevant critical review of the intellectual content and final approval of the version to be published. 


\section{References}

1. Ministério da Saúde (BR). Secretaria de Atenção à Saúde. Departamento de ações programáticas estratégicas. Gestação de alto risco: Manual técnico. Brasília: Ministério da Saúde; 2012.

2. Morse ML, Fonseca SC, Barbosa MD, Calil MB, Eyer FPC. Mortalidade materna no Brasil: o que mostra a produção científica nos últimos 30 anos? Cad Saúde Pública. 2011; 27(4):623-8.

3. Huçulak MC, Peterlini OLG. Rede Mãe Paranaense Relato de experiência. Esp Saúde. 2014; 15(1):7786.

4. Fonsêca LAC, Pádua LB, Valadares Neto JD. Avaliação da qualidade da assistência pré-natal prestada às gestantes usuárias do sistema único de saúde. Rev Interdisciplinar NOVAPAFI. 2011; 4(2):40-45.

5. Takeda SMP. Avaliação de unidade de atenção primária: modificação dos indicadores de saúde e qualificação da atenção [dissertação]. Pelotas (RG): Universidade Federal de Pelotas; 1993.

6. Anversa ETR, Bastos GAN, Nunes LN, Dal Pizzol TS. Qualidade do processo da assistência pré-natal: unidades básicas de saúde e unidades de Estratégia Saúde da Família em município no Sul do Brasil. Cad Saúde Pública. 2012; 28(4):789-800.

7. Bassani DCH, Derlan CB, Chaves J, Kanitz L, Dipp T, Ghignatti B, Koepp J, Possuelo LG. Avaliação de pré-natal por indicador de qualidade. Rev Saúde Cienc Biol. 2015; 3(2):67-72.

8. Corrêa CRH, Bonadio IC, Tsunechiro MA. Normative prenatal evaluation at a philanthropic maternity hospital in São Paulo. Rev Esc Enferm USP. 2011; 45(6):1293-300.
9. Costa CSC, Vila VSC, Rodrigues FM, Martins CA, Pinho LMO. Características do atendimento prénatal na Rede Básica de Saúde. Rev Eletr Enf [Internet]. 2013 [citado 2016 fev 21]; 15(2):51622. Disponível em: http://www.fen.ufg.br/ revista/v15/n2/pdf/v15n2a26.pdf

10. Saavedra JS, Cesar JA. Uso de diferentes critérios para avaliação da inadequação do pré-natal: um estudo de base populacional no extremo Sul do Brasil. Cad Saúde Pública. 2015; 31(5):1003-14.

11. Santos Neto ET, Oliveira EM, Zandonade E, Gama SGN, Leal MC. O que os cartões de pré-natal das gestantes revelam sobre a assistência nos serviços do SUS da Região Metropolitana da Grande Vitória, Espírito Santo, Brasil? Cad Saúde Pública. 2012; 28(9):1650-62.

12. Silva MZN, Andrade AB, Bosi MLM. Acesso e acolhimento no cuidado pré-natal à luz de experiências de gestantes na Atenção Básica. Saúde Debate. 2014; 38(103):805-16.

13. Matumoto S, Vieira KCS, Pereira MJB, Santos CB, Fortuna CM, Mishima SM. Production of nursing care in primary health care services. Rev LatinoAm Enfermagem. 2012; 20(4):710-7.

14. Silva JN, Grossi ACM, Haddad MCL, Marcon SM. Avaliação da qualidade das anotações de enfermagem em unidade semi-intensiva. Esc Anna Nery. 2012; 16(3):576-81.

15. Winck DR, Brüggemann OM. Responsabilidade legal do enfermeiro em obstetrícia. Rev Bras Enferm. 2010; 63(3):464-9.

16. Tanaka OY. Avaliação da Atenção Básica em Saúde: uma nova proposta. Saúde Soc. 2011; 20(4):92734. 